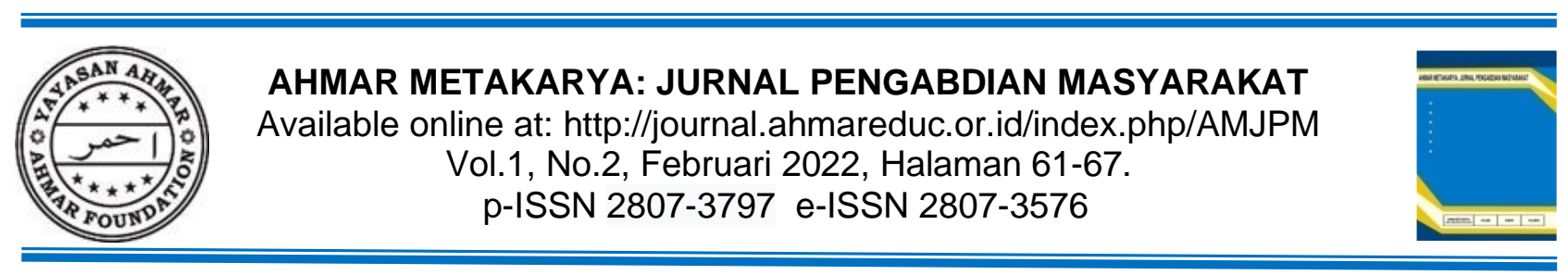

\title{
Peningkatan Pemahaman Pasangan Usia Subur Melalui Penyuluhan Keluarga Berencana
}

\author{
Andi Masnilawati ${ }^{\star}$, Nia Karuniawati, Sitti Hadriyanti Hamang \\ Fakultas Kesehatan Masyarakat, Universitas Muslim Indonesia, Makassar, Sulawesi Selatan, Indonesia \\ *Email: andi.masnilawati@umi.ac.id
}

Received: 10 Januari 2022

Accepted: 25 Februari 2022

Published: 28 Februari 2022

\begin{abstract}
The use of contraceptives, if not supported by good and consistent family planning knowledge, will have a negative impact on unwanted pregnancies which can eventually lead to abortion. Therefore, it is necessary to have a strong and consistent understanding of contraceptive methods in the selection and use of contraception. Long-term contraceptive methods have proven to be the most effective in reducing pregnancy rates. However, until now long-term contraceptive methods are still not an option for most couples of childbearing age in Indonesia. According to data from Taeng Village, Gantarang Village, where family planning was developed in 2021, the number of registered couples of childbearing age was 378 active family planning with details of $7.93 \%$ injections, $2.38 \%$ pills, $1.32 \%$ IUD/IUD and implants. . $2.11 \%$. Data shows that the use of long-term contraceptive methods is lower than short-term contraceptive methods, while long-term contraceptive methods are more effective than short-term contraceptive methods. The purpose of this community service is to increase the knowledge and understanding of couples of childbearing age about birth control through socialization and increasing types of contraceptives and their long-term use in Taeng Village, Kec. Pallangga, kab. Gowa. The method used in this service is the delivery of material about types of contraception and long-term contraceptive methods in the form of lectures, discussions and answers using powerpoints and leaflets for married couples as many as 14 people. The resulting coverage is an increase in community knowledge in Taeng Village with good knowledge (86\%), sufficient (14\%) and no more lack of knowledge about contraception. With the implementation of education through socialization and family planning counseling to enrich human life in Taeng Village, District. Pallangga, Gowa Regency, can increase the use of contraceptives in the community by introducing the mother's age, the number of children desired, and the mother's main health condition during the COVID-19 pandemic.
\end{abstract}

Keywords: Couples Of Reproductive Age, Contraception, Long-Term Contraceptive Methods.

\begin{abstract}
Abstrak
Penggunaan metode KB apabila tidak didukung oleh pengetahuan akseptor KB yang baik dan konsisten maka akan menimbulkan dampak diantaranya kehamilan tidak diinginkan yang kemudian dapat berimplikasi untuk terjadinya aborsi. Oleh sebab itu, maka diperlukan pemahaman yang kuat terkait metode kontrasepsi yang bertujuan untuk menguatkan konsistensi akseptor dalam memilih dan menggunakan metode kontrasepsi. Metode kontrasepsi jangka panjang (MKJP) terbukti paling efektif untuk menekan angka kehamilan. Namun, hingga saat ini MKJP masih belum menjadi pilihan mayoritas pasangan usia subur di Indonesia. Berdasarkan data Desa Taeng Dusun Gantarang tentang pecapaian peserta Keluarga Berencana ktif pada tahun 2021 jumlah Pasangan Usia Subur yang sebanyak 378 orang yang menjadi peserta KB aktif tercatat dengan rincian masing-masing yaitu Suntik 7,93\%, Pil 2,38\%, IUD/AKDR 1,32\% dan Implan 2,11\%. Data tersebut menunjukkan masih rendahnya angka pemakaian Metode Kontrasepsi Jangka Panjang dibandingkan non MKJP, padahal MKJP lebih efektif dibandingkan dengan non MKJP. Tujuan pengabdian ini meningkatan pengetahuan dan pemahamanpada Pasangan Usia Subur tentang KB melalui sosialisasi dan penyuluhan jenis-jenis alat kontrasepsi dan Metode Kontraspsi Jangka panjang di
\end{abstract}


Desa Taeng Kec. Pallangga, Kab. Gowa. Metode yang digunakanpada kegitan pengabdian ini yaitu pemberian edukasi materi jenis-jenis alat kontrasepsi dan Metode Kontrasepsi Jangka Panjang dengan metode ceramah, diskusi dan Tanya jawab menggunakan slide powerpoint dan leaflet pada Pasangan Usia Subur sebanyak 14 orang. Luaran yang telah dihasilkan yaitu terjadinya peningkatan pengetahuan masyarakat di desa Taeng dengan pengetahuan baik (86\%), cukup (14\%) dan tidak ada lagi yang pengetahuan kurang tentang alat kontrasepsi. Dengan adanya pemberian edukasi melalui sosialisasi dan penyuluhan KB kepada PasanganUsia Subur di Desa Taeng Kec. Pallangga Kab. Gowa dapat meningkatkan penggunaan KB pada masyarakat dengan pemilihan alat kontrasepi yang sesuai dengan umur ibu, jumlah anak diinginkan, dan kondisi kesehatan ibu utamanya di masa pandemic Covid-19.

Kata Kunci: Pasangan Usia Subur, Kontrasepsi, Metode Kontrasepsi Jangka Panjang.

\section{A. PENDAHULUAN}

Indonesia merupakan negara berkembang dengan jumlah penduduk yang besar dan laju pertumbuhan penduduk yang tinggi. Jumlah Penduduk Hasil Sensus Penduduk dan Survei Penduduk Antar Sensus Indonesia berada pada posisi keempat di dunia dengan estimasi jumlah penduduk terpadat, yaitu mencapai 269 603,4 juta jiwa, dengan laju pertumbuhan penduduk di Indonesia adalah sebesar 1,31\% atau setara dengan empat juta orang per tahun (BPS, 2019).

Program Keluarga Berencana merupakan salah satu program pemerintah yang diselenggarakan untuk membatasi kelahiran guna mengurangi pertumbuhan penduduk dan menurunkan laju penduduk. Program KB diatur berdasarkan UU No 10 Tahun 1992 dan disempurnakan lagi dengan terbitnyaUU No 52 Tahun 2009. Program KB merupakan upaya mengatur kelahiran anak, jarak, dan usia ideal melahirkan, mengatur kehamilan, melalui promosi, perlindungan dan bantuan sesuai dengan hak reproduksi untuk mewujudkan keluarga yang berkualitas (UU No.52 Pasal, 2009). Tujuan dari program KB pada dasarnya yaitu pengaturan kelahiran guna membangun keluarga sejahtera (Sulistyawati, 2011).

Penggunaan metode KB apabila tidak didukung oleh pengetahuan akseptor KB yang baik dan konsisten maka akan menimbulkan dampak diantaranya kehamilan tidak diinginkan yang kemudian dapat berimplikasi untuk terjadinya aborsi (Yadav and Dhillon, 2015). Oleh sebab itu, maka diperlukan pemahaman yang kuat terkait metode kontrasepsi yang bertujuan untuk menguatkan konsistensi akseptor dalam memilih dan menggunakan metode kontrasepsi Pemilihan metode kontrasepsi dipengaruhi oleh beberapa faktor diantaranya pengetahuan, jarak ke tempat pelayanan KB, biaya kontrasepsi, serta dukungan suami dan keluarga maupun teman (Mai Do, 2017).

Metode kontrasepsi jangka panjang (MKJP) terbukti paling efektif untuk menekan angka kehamilan. Namun, hingga saat ini MKJP masih belum menjadi pilihan mayoritas pasangan usia subur di Indonesia. Jenis MKJP seperti AKDR, AKBK, dan sterilisasi berupa vasektomi dan tubektomi telah terbukti secara ilmiah sebagai metode paling efektif menjarangkan kehamilan. namun, pengguna MKJP di Indonesia kalah jauh dari metode pil KB dan suntikpadahal MKJP lebih efektif dibandingkan dengan non MKJP (Setiawati, et al., 2019).

Desa Taeng sebagai salah satu desa yang terletak di kecamatan Pallangga berjarak kurang lebih3 km dari ibukota Kecamatan. Batas-batas administratif pemerintahan Desa Taeng Kecamatan Pallangga yaitusebelah Utara berbatsan dengan Sungai Je'neberang, sebelah Selatan berbatasan dengan Desa Kanjilo Kec. Barombong, sebelah Barat berbatsan dengan Desa Tamannyeleng Kec. Barombong dan sebelah Timur berbatsangan dengan Desa Bontoala. Wilayah Desa Taeng sekitar 2,27 Km2 yang terdiri dari 2 Dusun dengan jumlah penduduk Desa Taeng sekitar 12.385 .000 jiwa.

Berdasarkan survei pendahuluan yang dilakukan dan wawancara pada kepala desa dan Bidan Desa Taeng Dusun Gantarang tentang pecapaian peserta KB aktif pada tahun 2021 jumlah Pasangan Usia Subur yang sebanyak 378 orang yang menjadi peserta KB aktif tercatat dengan rincian masing-masing yaitu Suntik 7,93\%, Pil 2,38\%, IUD/AKDR 1,32\% dan Implan 2,11\%. Data tersebut menunjukkan masih rendahnya angka pemakaian MKJP dibandingkan non MKJP. Hasil wawancara tersebut juga mengungkapkan bahwa cukup banyak peserta KB dengan tidak rasional (tidak sesuai dengan umur ibu, jumlah anak yang diinginkan, dan kondisi kesehatan ibu). Salah 
satu faktor rendahnya kualitas dalam program KB khusunya metode MKJP adalah kurangnya pengetahuan masyarakat pada program KB yang ada. Hal tersebut diperkuat oleh penelitian Puspita (2012) menyebutkan bahwa menurunnya kuantitas dan kualitas program KB akibat rendahnya pemahaman masyarakat tentang pentinya program KB.

Berdasrkan analisis situasi salah satu masalah kesehatan yang terdapat Desa Taeng yaitu masih kurangnya pengetahuan Pasangan Usia Subur tentang jenis-jenis metode kontraspsi khususnya yang berkaitan dengan Metode Kontrasepsi Jangka Panjang dalam pengendalian kelahiran maka solusi yang ditawarkan yaitu untuk melakukan sosialisasi dan penyuluhan Keluarga Berencana pada Pasangan Usia Subur tentang jenis-jenis alat kontrasepsi dan Metode Kontrasepsi Jangka Panjang.

Pengabdian ini bertujuan untuk meningkatan pengetahuan dan pemahaman tentang $\mathrm{KB}$ melalui sosialisasi dan penyuluhan jenis-jenis alat kontrasepsi dan Metode Kontraspsi Jangkapada Pasangan Usia Subur di Desa Taeng Kec. Pallangga, Kab. Gowa.

\section{B. METODE DAN PELAKSANAAN}

Pelaksanaan kegiatan pengabdian masyarakat ini dilaksanakan di Kampung Rewako Dusun Gantarang Desa Taeng Kec. Pallangga, Kab. Gowa pada tanggal 10 April 2021 dengan jumlah peserta sebanyak 14 orang. Adapun metode yang digunakan dalam penyuluhan kesehatan ini adalah metode ceramah, diskusi dan tanya jawab. Selain itu, metode lain yang juga digunakan adalah pembagian leaflet dan kuesioner untuk mengukur tingkat pengetahuan dan pemahaman peserta pengabdian. Pelaksanaan kegiatan pengabdian melalui berbagai tahapan,antaralain:

\section{Tahap Persiapan}

Adapun tahapan persiapan (pra planning),yaitu antara lain:

a. Berkoordinasi dengan mitra yang terkait antara lain pemerintahan desa dan Bidan desa untuk melakukan sosialisasi dan penyuluhan pada Pasangan Usia Subur tentang jenis-jenis alat kontrasepsi dan metode kontrasepsi jangka panjang.

b. Melakukan pertemuan dengan Bidan desa dan kader untuk menjelaskan tentang pelaksanaan kegiatan berupa sosialisai dan penyuluhan pada Pasangan Usia Subur tentang jenis-jenis alat kontrasepsi dan metode kontraspsi jangka panjang.

c. Mempersiapkan materi yang akan di pakai selama proses kegiatan.

\section{TahapPelaksanaan}

Pada tahap ini di bagi menjadi dua tahapan, yaitu:

a. Tahap pertama : kegiatan diawali dengan pre-test pada saat pertemuan pertama

b. Tahap kedua : sosialisai dan penyuluhan dengan metode ceramah, diskusi dan tanya jawab pada Pasangan Usia Subur mengenai jenis-jenis KB dan metode kontraspsi jangka panjang yang didampingi oleh Bidan desa dan kader di wilayah Desa Taeng yang dibantu oleh tim.

\section{Tahap Evaluasi PelaksanaanProgram dan Keberlanjutan Kegiatan}

a. Kegiatan sosialisasi dan penyuluhan akan dievaluasi dengan pre post-test untuk mengukur besar perubahan pengetahuan dan pemahaman peserta dengan menggunakan kuesioner yang terdiri dari 10 pertanyaan dengan kategori baik jika peserta menjawab 7 benar, cukup jika menjawab 5 benar dan kurang jika menjawab 3 benar.

b. Dilakukan kunjugan untuk observasi keberfungsian sosialisasi dan penyuluhan.

c. Keberlanjutan Program

d. Terjadi peningkatan kesadaran Pasangan Usia Subur untuk menggunkan kontrasepsi Metode Kontrasepsi Jangka Panjang pada Wanita usia Subur di wilayah Desa Taeng setelah diberikan sosialisasi dan penyuluhan..

e. Setelah program ini selesai, Pasangan Usia Subur yang telah paham dapat secara berkelanjutan memberikan dan menyebarluaskan informasi tentang metode kontrasepsi 
jangka panjang kepada baik itu untuk keluarga maupun kepada sesama warga dengan memanfaatkan leaflet yang telah di bagikan.

\begin{tabular}{c}
$\begin{array}{c}\text { Berkordiasi } \\
\text { dengan } \\
\text { mintra }\end{array}$ \\
$\begin{array}{c}\text { Persiapan } \\
\text { pelaksanaan }\end{array}$ Pre-test $\begin{array}{c}\text { Pemberian } \\
\text { edukasi KB }\end{array}$ Post-tes $\begin{array}{c}\text { Evaluasi } \\
\text { keberlanjutan } \\
\text { kegiatan }\end{array}$ \\
\hline
\end{tabular}

Gambar 1. Alur tahapan kegiatan pengabdian.

\section{HASIL DAN PEMBAHASAN}

Kepala desa Taeng dibantu oleh Bidan desa dan Kader desa membantu untuk memfasilitasi dalam melakukanpemberian edukasi tentang KB yang salah satunya yaitu, mengarahkan Pasangan Usia Subur untuk mengukuti kegiatan pengabdian. Pasangan Usia Subur yang menjadi peserta kegiatan pengabdian. Pelaksanaan kegiatan sosilaisasi dan penyuluhan jens-jenis KB dan Metode Kontrasepsi Jangka Panjangdilakukan pada tanggal 10 April 2021 di Kampung Rewako Dusun Gantarang Desa Taeng Kec. Pallangga, Kab. Gowayang diikuti oleh Pasangan Usia subur sebanyak 14 orang

Pemberian edukasi materi jenis-jenis alat kontrasepsi dan metode kontrasepsi jangka panjang dilakukan oleh tim pengabdian/pamateri dilakukan dengan bantuan slide powerpoint dan leaflet yang disampiakan dengan metode ceramah. Materi ini berisi tentang apa yang dimaksud dengan alat kontrasepsi atau KB, jenis-jenis alat kontrasepsi dengan metode jangka panjang (MKJP), tujuan, manfaat, efek samping, dan cara pemakaian atau pemasangan alat kontrasepsi. Pada akhir pemberian materi dibuka sesi Tanya jawab dan ada beberapa Pasangan Usia Subur yang bertanya berkaitan dengan materi yang disampaikan diantaranya "apakah benar bahwa penggunaan alat kontrasepsi IUD dan Implant bisa bisa berpindah tempat?".
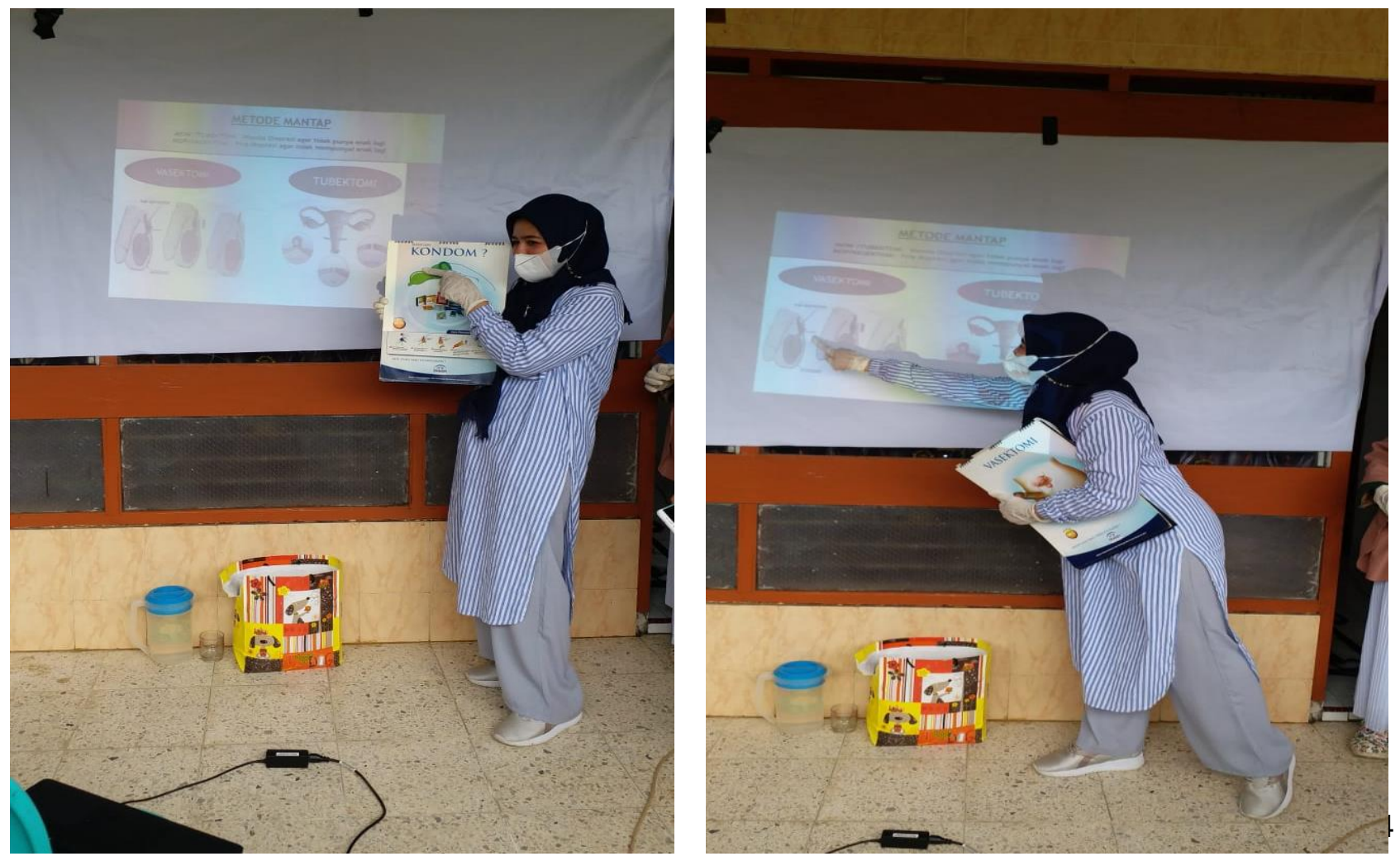


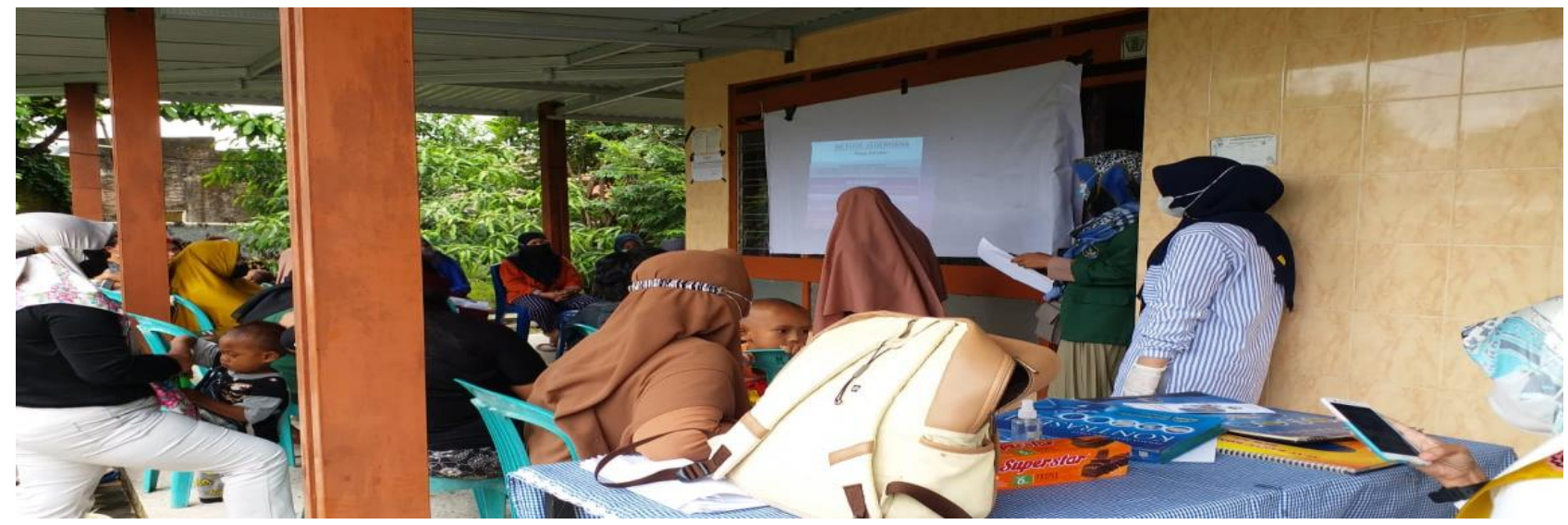

Gambar 1. Pemberian edukasi materi KB

Pelaksanan kegiatan sosialisasi dan penyuluhan dievalusi dengan pre post test untuk mengukur besar perubahan pengetahuan dan pemahaman peserta dengan menggunakan kuesioner yang terdiri dari 10 pertanyaan dengan kategori baik jika peserta menjawab 7 benar, cukup jika menjawab 5 benar dan kurang jika menjawab 3 benar. Tes ini dilakukan pada 14 orang Pasangan Usia Subur. Adapun hasil dari pre-test yang dilakukan pada 14 lbu Pasangan Usia Subur yaitu : Cukup (29\%), Kurang (71\%) dan Baik $(0 \%)$ dan setelah diberikan edukasi hasil posttest yang dilakukan yaitu : Baik : (86\%), Cukup (14\%), tidak ada lagi yang pengetahuan kurang tentang jenis-jenis alat kontrasepsi. Dari hasil tersebut telihat bahwa ada peningkatan pengetahuan.
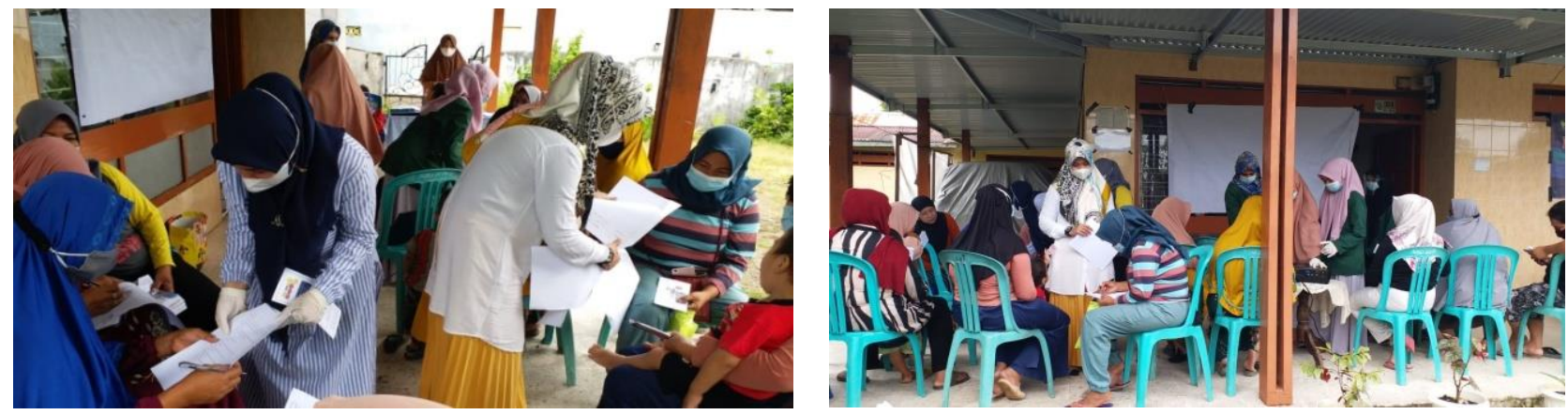

Gambar 2. Pembagian kuesioner Pre-test/Post-test
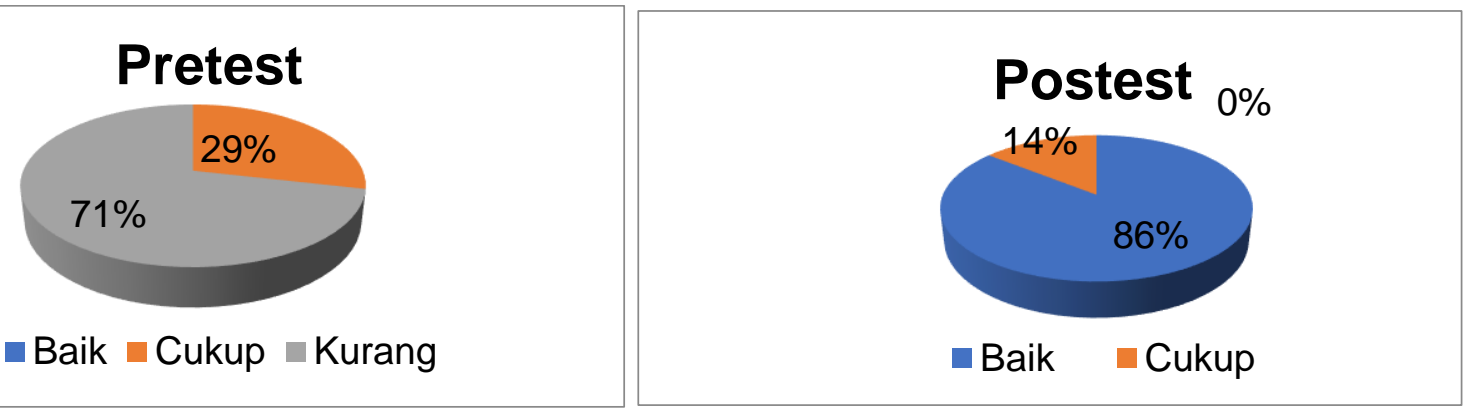

Gambar 3. Pengetahuan Pasangan Usia Subur tentang KB di Desa Taeng Kec Pallangga Kab. Gowa

Selain pemberian edukasi materi KB tim pengabdian juga membagikan Leaflet sebagai bagian dari kegiatan pengabdian yang dilakukankepada Pasangan Usia Subur di Desa Taeng Kec. Pallangga Kab. Gowa. 


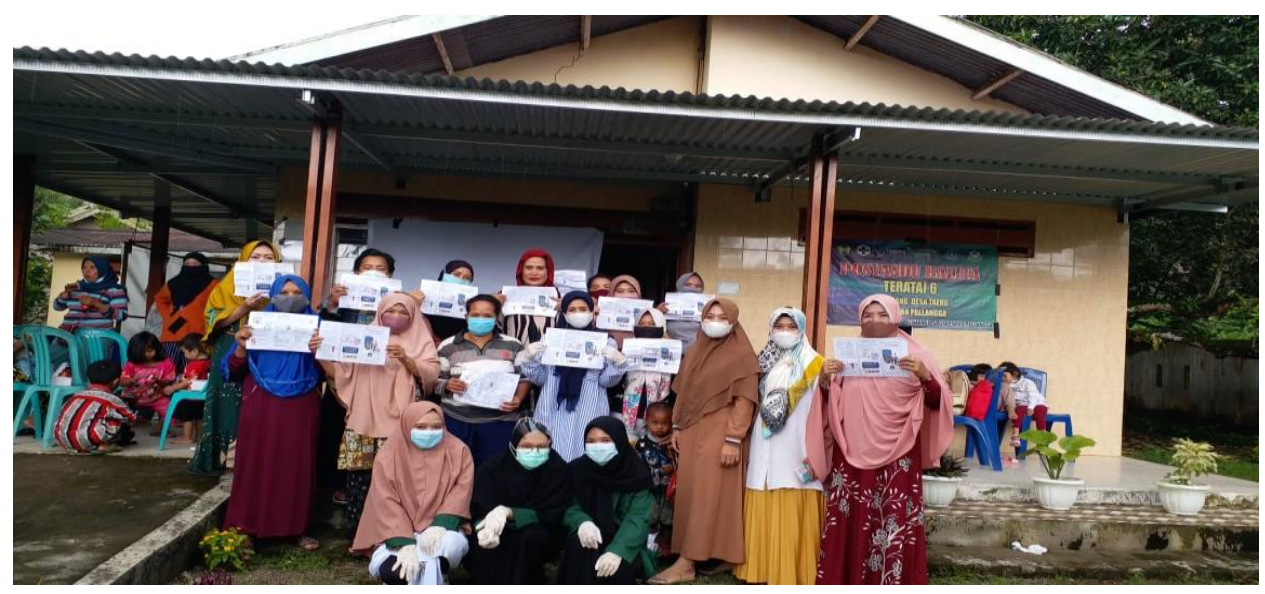

Gambar 4. Pembagian Leaflet

Diharapkan setelah melakukan sosialisai dan penyuluhan pada Pasangan Usia Subur akan menambah pengetahuan tentang jenis-jenis alat kontrasepsi dan metode kontraspsi jangka panjang serta memiliki keinginan untuk menggunakan KB metode kontraspsi jangka panjang. Hasil kegiatan pengabdian yang dilakukan oleh tim sejalan dengan beberapa kegiatan pengabdian sebelumnya bahwa adanya peningkatan pengetahuan setelah diberikan penyuluhan tentang KB, Kegiatan edukasi yang diberikan kepada wanita usia subur terkait KB dan metode kontrasepsi yang meliputi definisi KB,jenis-jenis metode kontrasepsi, keunggulan masing-masing metode kontrasepsi, dan efek samping yang bisa ditimbulkan dari penggunaan metode kontrasepsi. Berdasarkan hasil kegiatan dapat diketahui bahwa metode penyuluhan yang dilakukan dapat meningkatkan pengetahuan WUS tentang KB dan hasil pre-test dan post-test kegiatan pengabdian kepada masyarakat menunjukkan hasil penyuluhan pada WUS di wilayah puskesmas Sangkrah Kota Surakarta tahun 2016 yang menunjukkan bahwa terjadi peningkatan nilai mean pengetahuan metode kontrasepsi sebelum dan sesudah penyuluhan (Matahari, et al., 2021);

Dengan adanya pemberian edukasi dan penyuluhan tentang KB yang dilakukan dengan bantuan slide powerpoint dan leaflet kepada Pasangan Usia Subur di Desa Taeng Kec. Pallangga Kab. Gowa dapat meningkatkan penggunaan KB pada masyarakat dengan pemilihan alat kontrasepi yang rasional sesuai dengan umur ibu, jumlah anak yang diinginkan, dan kondisi kesehatan ibu utamanya di masa-masa pandemic Covid-19 saat ini.Untuk mendapatkan pemahaman yang baik maka perlu didukung dengan cara penyampaian informasi secara informative. Oleh karena itu,metode penyampaian informasi menjadi hal penting dalam pemberian edukasi.Teknik penyuluhan dipilih karena merupakan cara penyampaian materi yang interaktif dengan audiences dibandingkan dengan metode diskusi kelompok (Masturo, et al., 2019). Selain itu, media penyampaian materi juga memberikan penilaian tersendiri oleh kelompok sasaran. Media powerpoint yang berisikan gambar-gambar akan mudah diingat dan dipahami oleh kelompok sasaran (Dewi, 2018). Pengetahuan yang baik juga merupakan faktor yang memotivasi seseorang untuk memutuskan menggunakan metode kontrasepsi yang sesuai dengan kondisi dan kebutuhan WUS (Harini, et al., 2019).

Harapanya setelah program ini selesai,dapat secara berkelanjutan memberikan dan menyebarluaskan informasi tentang metode kontrasepsi jangka panjang kepada baik itu untuk keluarga maupun kepada sesama warga dengan memanfaatkan leaflet yang telah di bagikan. Sejalan dengan kajian ilmiah sebelumnya yang menunjukkan bahwa penyuluhan, pemberian leaflet dan brosur juga dapat meningkatkan kesadaran dan perilaku seseorang (Andriani, et al., 2020).

\section{KESIMPULAN}


Kegiatan terlaksana sesuai dengan tujuan dan rencana, kegiatan ini mendapat sambutan baik dan antusiasme yang tinggi pemerintah dan warga setempat, Kegiatan Pengabdian Masyarakat ini dilakukan dengan tujuan untuk ini meningkatan pengetahuan dan pemahaman pada Pasangan Usia Subur tentang KB melalui sosialisasi dan penyuluhan jenis-jenis alat kontrasepsi dan Metode Kontraspsi Jangka panjang di Desa Taeng Kec. Pallangga, Kab. Gowa dan membantu masyarakat desa Taeng dalam mengendalikan angka kelahiran dan meningkatkan minat Pasangan Usia Subur untuk menggunakan Metode Kontrasepsi Jangka Panjang utamanya dimasa pandemik Covid-19. Diharapkan kepada mitra agar dapat menjaga kesinambungan program pengabdian kepada masyarakat antara dengan memanfaatkan Leaflet yang telah dibagikan.

\section{UCAPAN TERIMA KASIH}

Ucapan terimakasih yang sebesar-besarnya kami ucapkan kepada Kepala Desa Taeng Kec. Pallangga Kab. Gowa yang telah memberikan izin dan dukungan terhadap pelaksanaan kegiatan. Bidan desa dan Kader yang ikut membantu untuk memfasilitasi dalam melakukan sosilaisasi dan penyuluhan jens-jenis KB dan Metode Kontrasepsi Jangka Panjang. Universitas Muslim Indonesia yang telah memberikan dukungan fasilitas terhadap pelaksanaan kegiatan pengabdian.

\section{DAFTAR PUSTAKA}

Andriani, Y., Suwarni, L. and Arfan, I. (2020). Mini Poster Berbahasa Daerah Sebagai Alternatif Media Promosi Kesehatan Kepatuhan Mencuci Tangan. Jurnal Ilmiah Kesehatan, 2(1), pp. 9-18. doi: 10.36590/jika.v2i1.38.

BPS. (2019). Jumlah Penduduk Hasil Proyeksi Menurut Provinsi dan Jenis Kelamin 2018-2020. Badan Pusat Statistik.

Dewi, R. A. (2018). Pengaruh Keterlibatan Suami dalam Penyuluhan terhadap Pengetahuan dan Minat Penggunaan Alat Kontrasepsi Modern pada Unmet Need Kampung KB di Kota Yogyakarta. Skripsi. Yogyakarta: Poltekkes Kemenkes Yogyakarta.

Harini, P., Lusiana, A. and Widatiningsih, S. (2019). The Influence of Health Education Toward the Level of Knowledge and Motivation in the Use of Family Planning Programs With the LongTerm Method of Contraception. Midwifery and Nursing Research, 1(2), p. 96. doi: 10.31983/manr.v1i2.5290.

Mai Do, R. S. (2017). Women's Empowerment and Modern Contraceptive Use Among Young, Married Women in South and Southeast Asia', 102(4), pp. 24-25.

Masturo, U., Kholisotin, K. and Agustin, Y. D. (2019). Efektifitas Penyuluhan Kesehatan Tentang SADARI dengan Metode Diskusi Kelompok dan Metode Demonstrasi terhadap Perilaku WUS dalam Melakukan SADARI. Citra Delima: Jurnal IImiah STIKES Citra Delima Bangka Belitung, 3(2), pp. 141-154. doi: 10.33862/citradelima.v3i2.86.

Matahari, R., Rachmawati, F. A. and Rasella, A. (2021). PKM Edukasi Keluarga Berencana dan Metode Kontrasepsi pada Wanita Usia Subur di Kecamatan Jetis. E-Dimas: Jurnal Pengabdian kepada Masyarakat, 12(1), pp. 137-141. doi: 10.26877/e-dimas.v12i1.6025.

Puspitawati, H. 2012. Gender dan Keluarga: Konsep dan Realita di Indonesia. Bogor: IPB Press

Setiawati, E., Sundari, S. and Nasifah, I. (2019) 'Deteksi Dini Pemakaian MKJP (Metode Kontrasepsi Jangka Panjang) Pada Wanita Usia Subur Di Desa Candirejo Mijen Kab.Semarang', Jurnal Pengabdian Dharma Bakti, 2(2), p. 13. doi: 10.35842/jpdb.v2i2.84.

Sulistyawati, A. (2011). Pelayanan keluarga berencana. Jakarta: Salemba Medika.

UU No. 52 Pasal (2009). Perkembangan Kependudukan dan Pembangunan Keluarga.

Yadav, D. and Dhillon, P. (2015). Assessing the impact of family planning advice on unmet need and contraceptive use among currently married women in Uttar Pradesh. India, PLoS ONE, 10(3), pp. 1-16. doi: 10.1371/journal.pone.0118584. 